\title{
Pengaruh Persepsi Kemanfaatan dan Kemudahan Penggunaan Terhadap Penerimaan Sistem E-Learning Di SMK Negeri 4 Kota Sorong
}

\author{
Muhammad Jundullah ${ }^{1,{ }^{*}}$, Rusydi Umar ${ }^{2}$, Anton Yudhana ${ }^{3}$ \\ ${ }_{1}^{1}$ Magister Teknik Informatika; Universitas Ahmad Dahlan; Jalan Prof. Dr. Soepomo, Janturan, \\ Yogyakarta, 55164; e-mail: muhammad1808048039@webmail.uad.ac.id \\ 2 Teknik Informatika; Universitas Ahmad Dahlan; Jalan Ring Road Selatan, Tamanan \\ Banguntapan Bantul, Yogyakarta, 55166; e-mail: rusydi umar@rocketmail.com \\ ${ }^{3}$ Teknik Elektro; Universitas Ahmad Dahlan; Jalan Ring Road Selatan, Tamanan Banguntapan \\ Bantul, Yogyakarta, 55166; e-mail: eyudhana@ee.uad.ac.id \\ * Korespondensi: e-mail: muhammad1808048039@webmail.uad.ac.id
}

Diterima: 10 Mei 2021; Review: 22 Mei 2021; Disetujui: 02 Juni 2021

Cara sitasi: Jundullah M, Umar R, Yudhana A. 2021. Pengaruh Persepsi Kemanfaatan Dan Kemudahan Penggunaan Terhadap Penerimaan Sistem E-Learning Di SMK Negeri 4 Kota Sorong. Bina Insani ICT Journal. Vol. 8 (1): 12-21.

\begin{abstract}
Abstrak: Keberhasilan dari penerapan teknologi tidak lepas dari pada faktor penggunanya. Bagaimana sikap dari pengguna terhadap penerapan suatu teknologi yang ada. Model TAM merupakan metode pendekatan untuk mengetahui bagaimana sikap dari pengguna terhadap suatu teknologi. Tujuan dari penelitian ini adalah untuk mengetahui pengaruh sikap dari pengguna terhadap penerapan e-learning di SMK Negeri 4 Kota Sorong. Sikap pengguna didasarkan pada variabel persepsi kemanfaatan dan kemudahan penggunaan yang ada pada model TAM. Penelitian melibatkan 61 siswa jurusan TKJ di SMK Negeri 4 Kota Sorong sebagai responden. Data didapat dari penyebaran kuesioner menggunakan google form. Pengolahan data menggunakan software SPSS dilakukan dengan uji validitas dan reliabilitas. Kemudian dilakukan Analisa data dengan uji t dan uji $\mathrm{F}$ untuk mengetahui hasil. Hasilnya didapat adalah dari persepsi kemudahan pengguna dan persepsi kemanfaatan berpengaruh positif terhadap penerimaan e-learning di SMK Negeri 4 Kota Sorong.
\end{abstract}

Kata kunci: e-learning, persepsi kebermanfaatan, persepsi kemudahan penggunaan, penerimaan sistem, TAM.

\begin{abstract}
The success of the implementation of technology cannot be separated from the user factor. How is the user's attitude towards the application of an existing technology. The TAM model is a method approach to see how the attitudes of users towards a technology. The purpose of this study was to see the effect of user attitudes on the application of e-learning in SMK Negeri 4 Kota Sorong. Based on the perceived usefulness and perceived ease of use variables of the TAM model. The respondent are 61 students of SMK Negeri 4 Kota Sorong majoring in computer and network engineering (TKJ). Data obtained from distributing questionnaires using google forms. Data processing using SPSS software by performing validity tests, realibility tests. Then do data analysis with $t$ test and $F$ test to see the results. The results show that the perceived ease of use and perceived usefulness has a positive effect on the acceptance of e-learning at SMK Negeri 4 Kota Sorong.
\end{abstract}

Keywords: e-learning, perceived usefulness, perceived ease of use, system acceptance, TAM. 


\section{Pendahuluan}

Kebutuhan akan penggunaan teknologi saat ini sudah menjadi hal yang sangat umum dimasyarakat. Apalagi dengan adanya pandemi covid yang belum mereda sampai saat ini membuat segala urusan mulai dari pekerjaan dan kegiatan belajar mengajar semua menggunakan teknologi. Teknologi belajar mengajar jarak jauh atau biasa disebut E-learning merupakan salah satu model atau metode pembelajaran yang diusung oleh pemerintah menurut permendikbud no.109 2013 tentang penyelenggaraan pendidikan jarak jauh di perguruan tinggi [1].

E-learning dapat membantu guru dan siswa dalam memberikan materi pembelajaran dan menerima materi pembelajaran [2].

E-learning dapat digunakan malalui jaringan internet, intranet atau media lain [3]. Jadi, dengan adanya e-learning ini, walaupun siswa sedang tidak berada di dalam kelas siswa tetap dapat mengakses pelajaran.

Keberhasilan dari penerapan e-learning tentu saja tidak lepas dari penggunanya. Menurut Thompson didalam [4] aspek perilaku pengguna berperan penting dalam penerapan penggunaan teknologi. Sikap pengguna terhadap suatu sistem akan bersifat positif ketika suatu sistem dirasa bermanfaat dan dapat memecahkan suatu masalah.

Oleh karena itu, perlu dipahami bahwa perilaku merupakan salah satu aspek penting dalam penerapan teknologi. Karena penggunaan teknologi dipengaruhi oleh sikap sebagai aspek perilaku dari seseorang yang menggunakan teknologi [4].

Salah satu model yang umum digunakan sebagai metode pendekatan untuk mengukur penerimaan teknologi adalah Technology Acceptance Model (TAM). Model TAM merupakan model penerimaan teknologi yang akan digunakan pengguna, TAM dikembangkan oleh Davis et al. (1989) TAM memiliki beberapa konstruk yaitu persepsi kemudahan penggunaan, persepsi kemanfaatan, sikap penggunaan teknologi, sikap untuk menggunakan, dan penggunaan teknologi yang sesungguhnya [5].

Model TAM didasarkan oleh dua konstruk dasar sebagai faktor sikap dari perilaku pengguna yaitu persepsi kemanfaatan dan kemudahan penggunaan [6].

Tujuan dari penelitian ini adalah untuk mengetahui pengaruh dari pada persepsi kemanfaatan dan kemudahan penggunaan terhadap penerimaan e-learning di SMK Negeri 4 Kota Sorong.

Penelitian ini dilakukan dengan awalan melihat dan pempelajari penelitian terdahulu diantaranya yang Pertama adalah Penelitian dari Nurmaini Dalimunthe dan Himawan Wibisono dengan judul Analisis penerimaan sistem E-learning di SMK Labor Pekan baru dengan mengunakan Technology Acceptance Model (TAM). Tujuan dari penelitian ini adalah untuk mengetahui dan mengukur persepsi siswa terhadap kegunaan dan kemudahan penggunaan, serta faktor-faktor yang mendorong siswa untuk menggunakan e-learning di SMK Labor Pekanbarru. Hasil yang diperoleh menunjukkan untuk persepsi kemudahan penggunaaan adalah $97,45 \%$ dengan kategori sangat puas dan untuk persepsi kemanfaatan adalah $97,45 \%$ dengan kategori sangat puas [7].

Kedua adalah penelitian dari Subakdo Eko Yulianto yang melakukan penelitian utnuk mengkaji tentang penerimaan teknologi informasi terhadap kemanfaatan e-learning sesuai dengan metode TAM. Hasil yang diperoleh dalam penelitian ini ditunjukkan dengan persepsi kemudahan penggunaan mempunyai pengaruh positif yang signifikan terhadap penggunaan $e-$ learning dan dari persepsi kemanfaatan juga mempunyai pengaruh positif yang signifikan terhadap penggunaan e-learning di SMK Muhammadiyah 3 Yogyakarta [4].

Ketiga, Penelitian dari Agusdi Syafriza, Ernawati dan B. Yudi Dwiandiyanta isi penelitian yaitu alur penerapan model tam dalam mengetahui hasil penerapan pada media pembelajaran berbasis multimedia interaktif [8].

Keempat, penelitian dari Ockhy Jey Fhiter dengan judul penelitian pengukuran kesuksesan implementasi e-learning dengan metode TAM dan UTAUT. Tujuan dari penelitian ini yaitu untuk mengetahui keberhasilan dari implementasi sistem e-learning yang ada pada Universitas ZZP Yogyakarta menggunakan model TAM dan UTAUT. Peneliti menggunakan semua variabel dari metode tam dan utaut untuk mengukur data dengan menggunakan kuesioner yang disebar pada 30 responden yang merupakan mahasiswa Fakultas Ekonomi pada Universitas ZZP Yogyakarta. Kemudian dianalisa menggunakan software SPSS. Berdasarkan hasil Analisa didapat hasil yang menunjukkan kesuksesan implementasi $e$ learning sebesar $66,75 \%$ dengan metode TAM menyatakan sukses dan sebesar $69,66 \%$ pada 
metode utaut menyatakan sukses. Sehingga kesimpulannya e-learning yang telah diterapkan dapat di terima oleh responden [9].

Kemudian yang kelima ada dari penelitian Tuska Abe dengan tujuan penelitian menganalisis penerimaan pengguna terhadap penerapan aplikasi e-learning dengan menggunakan metode TAM. Penelitian dilakukan di SMA Huamual Barat Talaga dengan objek penelitian aplikasi e-learning yang diterapkan disekolah. Untuk mengukur tingkat persepsi pengguna terhadap tingkat penerimaan e-learning dilibatkan 35 siswa yang menjadi responden di SMA Huamual Barat Talaga. Analisa data menggunakan analisis deskriptif berdasarkan kategori dan presentase. Hasilnya menunjukkan aplikasi e-learning yang ada di SMA Talaga Huamual Barat mendapat persentase $98,09 \%$ setuju untuk persepsi kemanfaatan dan kemudahan penggunaan [10].

\section{Metode Penelitian}

\section{Technology Acceptance Model}

Technology Acceptance Model atau disingkat TAM merupakan model penerimaan sistem yang dikembangkan oleh Davis et al. (1989). Pengembangan TAM berdasarkan model TRA dengan konstruk utama, yakni perceived ease of use dan perceived usefulness [5]. Model TAM menjelaskan bahwa penerimaan sistem dipengaruhi dua variabel tersebut dijelaskan pada gambar 1.

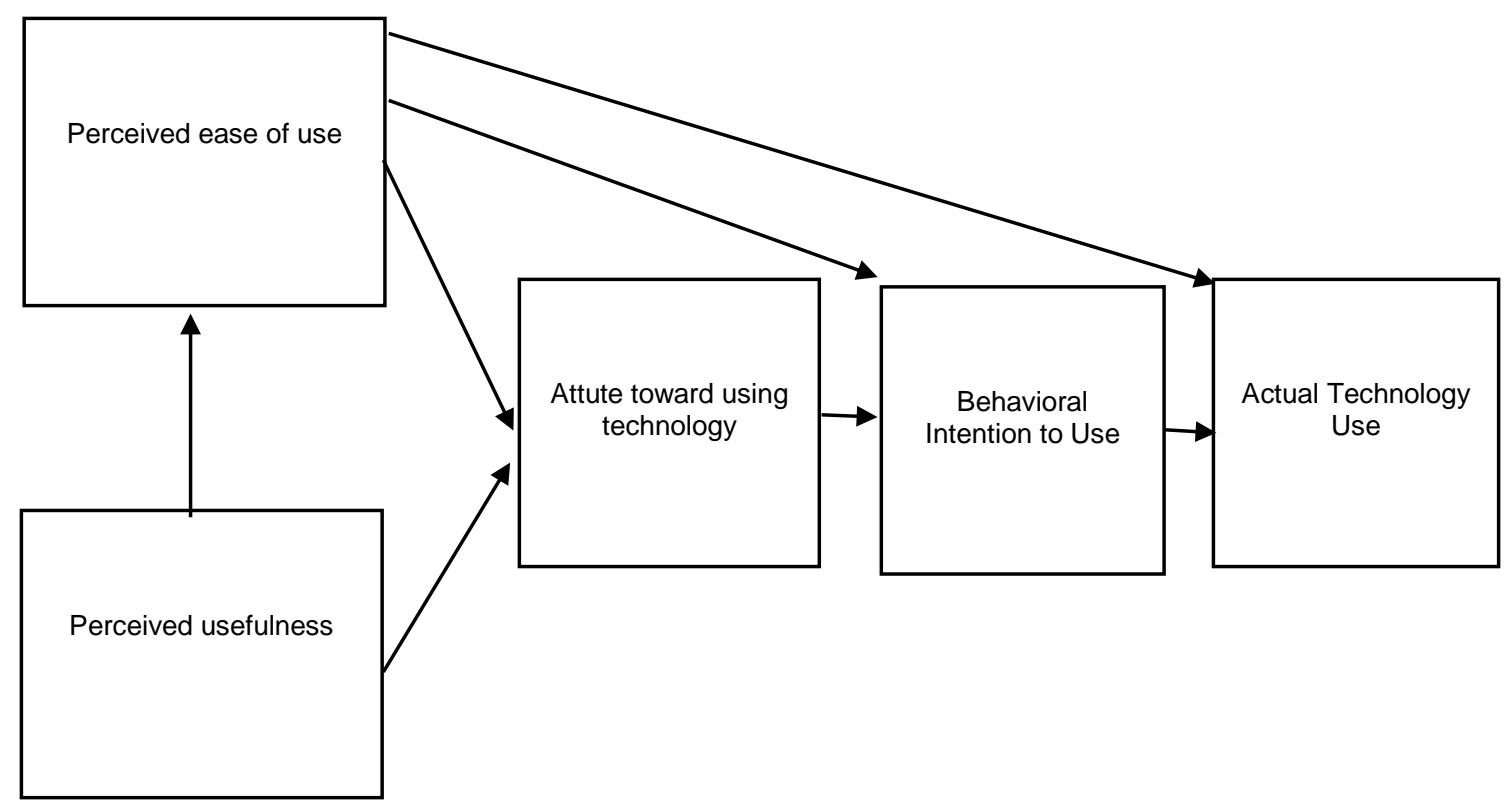

Sumber: Davis et al. (1989)

\section{Gambar 1. Bagan model TAM}

Dari gambar diatas dapat dilihat konstruk-konstruk dari model TAM: Perceived ease of use yang artinya persepsi kemudahan penggunaan merupakan kepercayaan dari seseorang yang menggunakan teknologi terbebas dari usaha [5].

Perceived usefulness atau persepsi kemanfaatan yang merupakan kepercayan dari seseorang yang menggunakan teknologi mendapat peningkatan kinerja pekerjaan [5].

Attitude toward using technology atau sikap terhadap penggunaan teknologi yang meripakan perasaan individu saat harus berperilaku yang ditentukan [5].

Behavioral intention to use atau niat periku untuk menggunakan yang merupakan keinginan untuk menunjukkan perilaku tertentu. Suatu individu akan keinginan untuk berperilaku yang ditentukan.

Actuall technology use atau penggunaan teknologi yang sesungguhnya yang dimaksud penggunaan teknologi sesungguhnya adalah perilaku yang dilakukan dalam konteks penggunaan sistem teknologi informasi [5]. 
Dalam penelitian ini hanya terfokus pada dua konstruk utama yaitu persepsi kemudahan penggunaan dan persepsi kemanfaatan yang akan dilihat apakah berpengaruh terhadap penerimaan sistem yang telah ada.

\section{Variabel yang diteliti}

Penelitian ini menggunakan variabel persepsi kemanfaatan dan persepsi kemudahan penggunaan dari model TAM yang digunakan sebagai indikator untuk mengukur sejauhmana tingkat berpengaruhnya kedua variabel tersebut terhadap penerimaan sebuah sistem yang diterapkan. Variabel penelitian dapat dilihat pada tabel1 dibawah ini.

Tabel 1. Variabel penelitian

\begin{tabular}{|c|c|c|}
\hline Dimensi & Definisi & Indikator \\
\hline $\begin{array}{l}\text { Perceived } \\
\text { Usefulness }\end{array}$ & $\begin{array}{l}\text { kepercayan dari seseorang yang menggunakan } \\
\text { teknologi mendapat peningkatan kinerja pekerjaan }\end{array}$ & $\begin{array}{l}\text { 1. Pekerjaan menjadi lebih cepat } \\
\text { 2. Kinerja pekerjaan } \\
\text { 3. Produktif } \\
\text { 4. Efektif } \\
\text { 5. Pekerjaan menjadi lebih mudah } \\
\text { 6. Bermanfaat }\end{array}$ \\
\hline $\begin{array}{l}\text { Perceived Ease } \\
\text { Of Use }\end{array}$ & $\begin{array}{l}\text { kepercayaan dari seseorang yang menggunakan } \\
\text { teknologi terbebas dari usaha }\end{array}$ & $\begin{array}{l}\text { 1. Kemudahan untuk dipelajari } \\
\text { 2. Dapat dikuasai } \\
\text { 3. Jelas atau dapat dimengerti } \\
\text { 4. Fleksibilitas } \\
\text { 5. Kemudahan untuk menjadi terampil } \\
\text { 6. Mudah digunakan }\end{array}$ \\
\hline $\begin{array}{l}\text { Penerimaan } \\
\text { Sistem }\end{array}$ & Sikap pengguna terhadap penggunaan sistem & $\begin{array}{l}\text { 1. Sikap } \\
\text { 2. Alasan } \\
\text { 3. Kelebihan sistem }\end{array}$ \\
\hline
\end{tabular}

Sumber: Hasil Penelitian (2021)

\section{Pengumpulan Data}

Pengumpulan data dilakukan dengan menggunakan kuesioner atau angket. Kuesioner berisikan beberapa butir pertanyaan yang berkaitan dengan variabel penelitian. Angket dibuat dengan menggunakan google form dan yang menjadi responden yaitu merupakan para siswa di SMK Negeri 4 Kota Sorong yang menggunakan e-learning.

Responden merupakan para siswa yang mengambil jurusan TKJ atau Teknik Komputer dan Jaringan yang berjumlah 93 siswa, dikarenakan jumlahnya tidak lebih dari 100 maka pengumpulan data akan melibatkan seluruh siswa jurusan TKJ.

Poin-poin pertanyaan pada kuisioner dibuat dengan menggunakan skala likert, dengan skala 4 seperti berikut.

1 = sangat tidak setuju

2 = tidak setuju

$3=$ setuju

4 = sangat setuju

\section{Uji Validitas dan Reliabilitas Data}

Uji validitas merupakan Teknik untuk mengetahui validitas dari instrumen penelitian yang diajukan [11]. Validitas sendiri menurut Ghozali didalam [12] suatu kuesioner dapat dinyatakan valid jika poin-poin pertanyaan didalam kuesioner dapat mewakilkan atau mengungkapkan sesuatu yang akan diukur.

Uji validitas dilakukan dengan melihat nilai sig masing-masing perangkat peneltian [13]. Nilai sig didapat dengan cara membandingkan $r$ hitung dan $r$ tabel untuk (df)=n-2, $n$ merupakan jumlah sampel. Jika nilai $r$ hitung lebih besar dari $r$ tabel dan nilainya positif berarti indikator dalam kuesioner dapat dikatakan valid. Dalam penelitian ini menggunakan SPSS untuk membantu pengukuran instrumen.

Uji Reliabilitas adalah ukuran konsistensi, satu kuisioner dikatakan reliabel jika respon dari individu terhadap suatu pernyataan konsisten atau stabil dari waktu ke waktu [12]. Menurut Sugiyono didalam [12] instrument yang valid biasanya pasti reliabel, tetapi tetap perlu melakukan pengujian reliabilitas. 


\section{Analisis regresi berganda}

Analisa regresi berganda terdiri dari pengujian uji t dan uji F. pengujian ini diperlukan untuk mengetahui seberapa besar variasi variabel bebas yang digunakan dalam penelitian dapat menjelaskan vriasi variabel terikat.

Uji t dilakukan untuk menguji pengaruh dari masing-masing variabel bebas terhadap variabel terikat. Sedangkan uji F dilakukan untuk menguji keseluruan variabel bebas bersamasama yang memiliki pengaruh signifikan terhadap variabel terikat [14].

\section{Hasil dan Pembahasan}

\section{Karakteristik responden}

Dari 93 responden, hanya 61 yang mengisi kuesioner yang diberikan. Keseluruhan siswa merupakan siswa jurusan TKJ di SMK Negeri 4 Kota Sorong dan sudah atau sedang menggunakan e-learning untuk kegiatan belajar. Untuk usia dan jenis kelamin dapat dilihat pada gambar berikut:

Dari gambar 2, dapat dilihat bahwa 54,1\% responden berjenis kelamin perempuan dan $45,9 \%$ berjenis kelamin laki-laki.

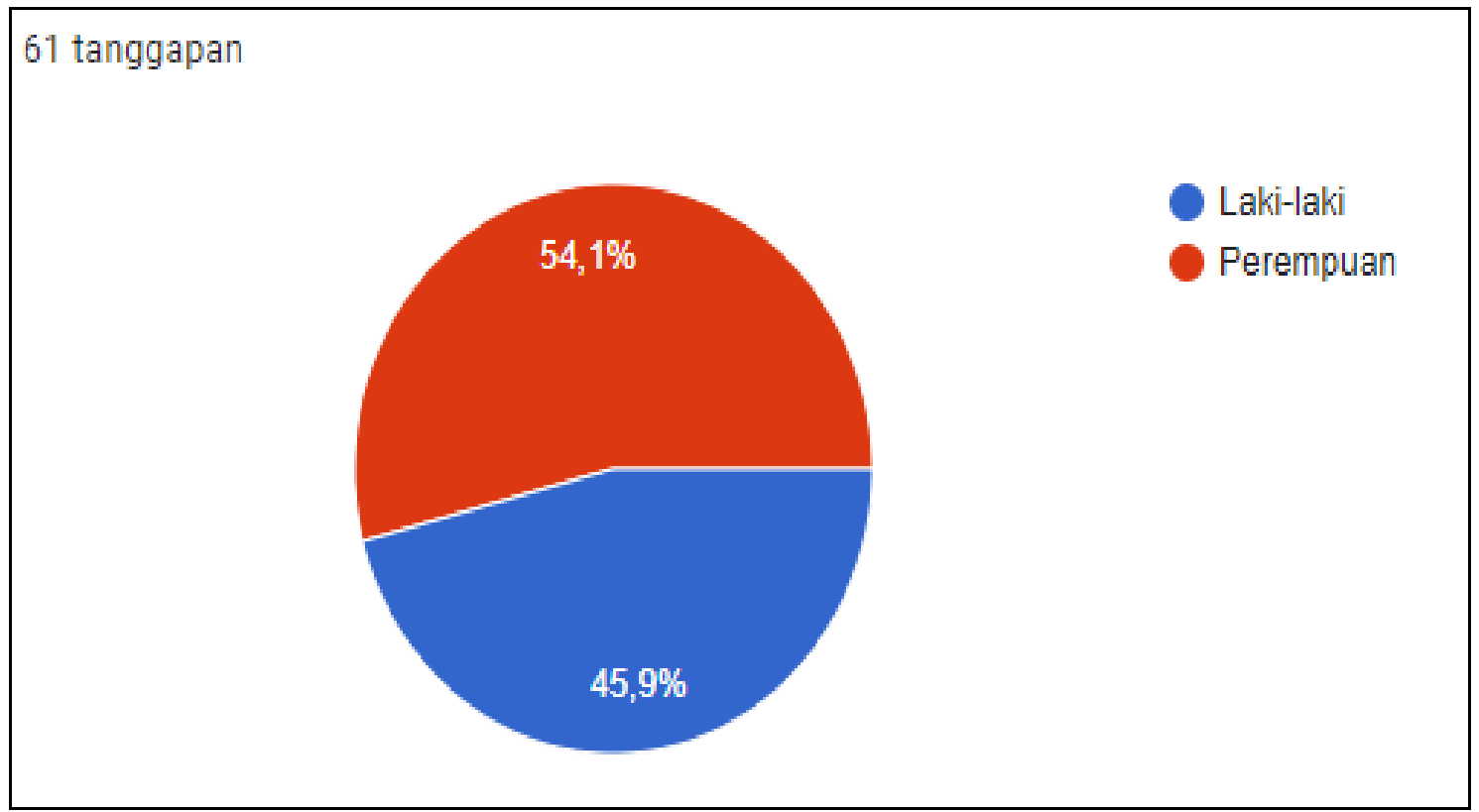

Sumber: Hasil Penelitian (2021)

Gambar 2. Diagram jenis kelamin responden

Dari gambar 3, dapat dilihat usia daripada para responden. Usia bervariasi mulai dari 13 sampai 19 tahun. Dengan total rata-rata usia 16 tahun. Usia 13 tahun terdapat 1 tanggapan atau sebesar $1,6 \%$, usia 15 tahun terdapat 20 tanggapan atau sebesar $32,8 \%$, usia 15 tahun terdapat 1 tanggapan atau sebesar $1,6 \%$, usia 16 tahun terdapat 11 tanggapan atau sebesar $18 \%$, usia 17 tahun terdapat 10 tanggapan atau sebesar $16,4 \%$, usia 17 tahun terdapat 3 tanggapan atau sebesar $4,9 \%$, usia 18 tahun terdapat 9 tanggapan atau sebesar $14,8 \%$, dan usia 19 tahun terdapat 6 tanggapan atau sebesar $9,8 \%$ yang dijelaskan pada gambar 3 . 


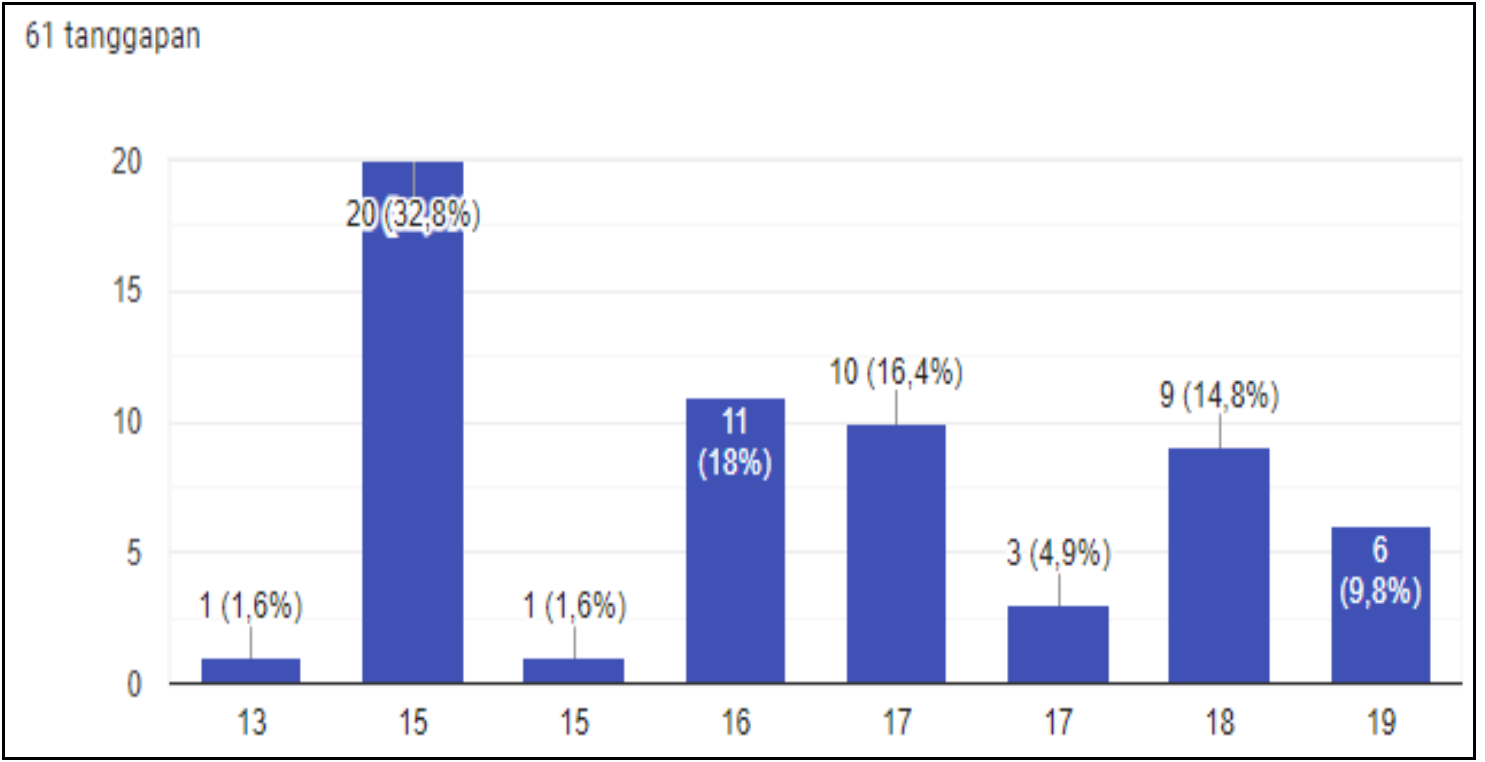

Sumber: Hasil Penelitian (2021)

\section{Uji Validitas}

Gambar 3. Diagram umur responden

Hasil uji validitas dilakukan dengan menggunakan software spss. Dalam uji validitas, sebuah item dikatakan valid apabila mempunyai nilai rhitung yang lebih besar dari pada nilai rtabel. Nilai rtabel dalam penelitian ini adalah 0.248. hasil dari uji validitas disajikan pada tabel berikut:

Dari tabel 1, didapat data bahwa semua item instrument yang digunakan dalam kuesioner didapat hasil Valid. Ini menunjukkan bahwa instrumen pertanyaan dalam kuesioner layak digunakan untuk penelitian ini atau valid untuk dilakukannya pengukuran.

Tabel 2. Hasil Uji Validitas

\begin{tabular}{cccc}
\hline item & rhitung & rtabel & keterangan \\
\hline PU1 & 0.744 & 0,248 & Valid \\
\hline PU2 & 0.677 & 0,248 & Valid \\
\hline PU3 & 0.755 & 0,248 & Valid \\
\hline PU4 & 0.750 & 0,248 & Valid \\
\hline PU5 & 0.708 & 0,248 & Valid \\
\hline PU6 & 0.808 & 0,248 & Valid \\
\hline PEU1 & 0.763 & 0,248 & Valid \\
\hline PEU3 & 0.656 & 0,248 & Valid \\
\hline PEU4 & 0.796 & 0,248 & Valid \\
\hline PEU5 & 0.792 & 0,248 & Valid \\
\hline A1 & 0.723 & 0,248 & Valid \\
\hline A2 & 0.712 & 0,248 & Valid \\
\hline
\end{tabular}

Sumber: Hasil Penelitian (2021)

\section{Uji Reliabilitas}

Hasil pengujian reliabilitas menggunakan nilai Cronbach alpha. Apabila nilai Cronbach alpha dari masing-masing variabel lebih besar dari nilai rtabel, maka variabel dapat dikatakan reliabel. Hasil pengujian reliabilitas disajikan dalam tabel berikut: 
Dari tabel 2, didapat hasil bahwa variabel yang digunakan dalam penelitian ini reliabel. Yang artinya variabel konsisten dan dapat digunakan dari waktu ke waktu.

Tabel 2. Hasil Uji Reliabilitas

\begin{tabular}{ccc}
\hline Variabel & nilai Cronbach alpha & Ket \\
\hline PU & 0.860 & reliabel \\
\hline PEU & 0.863 & reliabel \\
\hline Acceptance & 0.908 & reliabel \\
\hline
\end{tabular}

Sumber: Hasil Penelitian (2021)

\section{Analisis regresi berganda}

Pengambilan hipotesis didasarkan dengan menggunakan uji regresi berganda dengan uji t dan uji F. Dimana jika pada uji t, jika nilai sig kurang dari 0.05 atau thitung lebih dari nilai $t$ tabel berarti variabel $X$ berpengaruh kepada variabel $Y$ dan jika nilai sig lebih dari 0.05 atau $t$ hitung kurang dari nilai $t$ tabel berarti tidak ada pengaruh dari variabel $X$ kepada Variabel $Y$, disini variabel $x 1$ merupakan variabel $P U$ dan variabel $x 2$ merupakan variabel PEU dan variabel $\mathrm{y}$ adalah variabel $\mathrm{A}$ atau acceptance (penerimaan sistem).

Rumus untuk mengetahui nilai t tabel:

$\mathrm{t}$ tabel $=\mathrm{t}(\mathrm{\alpha} / 2 ; \mathrm{n}-\mathrm{k}-1)$

$=\mathrm{t}(0.05 / 2 ; 61-2-1)$

Keterangan:

$$
=\mathrm{t}(0.025 ; 58)
$$

$\mathrm{a}=$ tingkat kepercayaan (disini digunakan 0.05)

$\mathrm{n}=$ jumlah sampel

$\mathrm{k}=$ jumlah variabel $\mathrm{X}$

jika dilihat pada distribusi nilai $t$ tabel maka t $(0,024 ; 58)=2,00172$

Kemudian pada uji $\mathrm{F}$, jika nilai sig kurang dari 0.05 atau $\mathrm{F}$ hitung lebih dari $\mathrm{F}$ tabel berarti terdapat pengaruh variabel $\mathrm{X}$ keseluruhan terhadap variabel $\mathrm{Y}$. dan jika nilai sig lebih dari 0.05 atau $F$ hitung kurang dari $F$ tabel berarti tidak ada pengaruh dari variabel $X$ keseluruhan kepada variabel $\mathrm{Y}$.

Rumus untuk mengetahui nilai $F$ tabel:

$\mathrm{F}$ tabel $=\mathrm{F}(\mathrm{k} ; \mathrm{n}-\mathrm{k})$

$$
=F(2 ; 61-1)
$$

$=\mathrm{F}(2 ; 60)$

Keterangan :

$\mathrm{k}=$ jumlah variabel $\mathrm{X}$

$\mathrm{n}=$ jumlah sampel

jika dilihat pada distribusi nilai $F$ tabel

Didapatkan hasil dengan menggunakan software SPSS sebagai berikut:

Uji t

Uji t dilakukan untuk melihat pengaruh dari variabel yang ada yakni variabel persepsi kemdahan penggunaan dan variabel kemanfaatan terhadap penerimaan sistem. Dan didapat hasil sebagai berikut: berdasarkan gambar 4 , diketahui nilai t hitung dari pada variabel $P U$ adalah 6,016 dan nilai sig 0,000. berarti nilai sig $0,000<0,05$ dan nilai t hitung 6,016 $>$ dari nilai $t$ tabel yaitu 2,0017. Artinya variabel $P U$ berpengaruh terhadap penerimaan sistem. Kemudian, diketahui nilai t hitung pada variabel PEU adalah 3,164 dan nilai sig 0,002. 0,02<0,05 dan $3,164>$ dari 2,0017. Artinya variabel $P E U$ juga berpengaruh terhadap penerimaan sistem. 
BINA INSANI ICT JOURNAL ISSN: 2355-3421 (Print) ISSN: 2527-9777 (Online); 12 - 21

\begin{tabular}{|c|c|c|c|c|c|}
\hline \multicolumn{6}{|c|}{ Coefficients ${ }^{a}$} \\
\hline & \multicolumn{2}{|c|}{ Unstandardized Coefficients } & \multirow{2}{*}{$\begin{array}{c}\text { Standardized } \\
\text { Coefficients } \\
\text { Beta }\end{array}$} & \multirow[b]{2}{*}{$t$} & \multirow[b]{2}{*}{ Sig. } \\
\hline & B & Std. Error & & & \\
\hline (Constant) & 1.002 & .492 & & 2.039 & .046 \\
\hline PU & .282 & .047 & .618 & 6.016 & .000 \\
\hline PEU & .150 & .047 & .325 & 3.164 & .002 \\
\hline
\end{tabular}

Sumber: Hasil Penelitian (2021)

Gambar 4. Hasil SPSS uji t

\section{Uji F}

Uji F dilakukan untuk melihat pengaruh dari keseluruhan variabel persepsi kemudahan penggunaan dan variabel kemanfaatan terhadap variabel penerimaan sistem dijelaskan pada gambar 5 .

\begin{tabular}{|c|c|c|c|c|c|c|}
\hline & & & $O V A^{a}$ & & & \\
\hline Model & & $\begin{array}{l}\text { Sum of } \\
\text { Squares }\end{array}$ & $d f$ & Mean Square & $F$ & Sig. \\
\hline 1 & Regression & 153.467 & 2 & 76.733 & 141.211 & $.000^{\mathrm{b}}$ \\
\hline & Residual & 31.517 & 58 & .543 & & \\
\hline & Total & 184.984 & 60 & & & \\
\hline
\end{tabular}

Sumber: Hasil Penelitian (2021)

Gambar 5. Hasil SPSS uji F 
Dan didapat hasil berikut: berdasarkan gambar 5 diketahui nilai sig adalah 0,000 dan nilai $F$ hitung adalah 141,211 . Hasilnya $0,000<0,05$ dan nilai $F 141,211>3,15$. Berarti dapat disimpulkan bahwa variabel $\mathrm{X}$ keseluruhan yaitu variabel $P U$ dan $P E U$ berpengaruh terhadap variabel penerimaan sistem.

\section{Kesimpulan}

Dari hasil dan pembahasan sebelumnya untuk dua variabel yang ada pada TAM atau technology acceptance model yakni persepsi kemudahan penggunaan persepsi kemanfaatan dan bagaimana pengaruhnya terhadap penerimaan e-learning yang diterapkan di SMK Negeri 4 Kota Sorong. Kesimpulannya adalah sebagai berikut: Variabel persepsi kemanfaatan memiliki pengaruh positif pada penerimaan e-learning di SMK Negeri 4 Kota Sorong. Artinya e-learning yang diterapkan dirasa bermanfaat sehingga e-learning dapat diterima oleh para siswa yang menggunakannya. Variabel persepsi kemudahan penggunaan berpengaruh positif pada penerimaan e-learning di SMK Negeri 4 Kota Sorong. Artinya e-learning mudah digunakan sehingga e-learning dapat di terima oleh siswa yang menggunakannya. Kedua Variabel berpengaruh positif terhadap penerimaan e-learning SMK Negeri 4 Kota Sorong. Yang berarti para siswa selaku pengguna e-learning akan menerima e-learning Ketika sistem di rasa bermanfaat dan mudah digunakan.

\section{Referensi}

[1] M. A. M. Baihaqy, A. Rosidi, and A. S. Syahdan, "Analisis Usability Aplikasi E-Learning," J. Penelit. DAN Pengabdi. Kpd. Masy. UNSIQ, vol. 3, no. 3, pp. 159-173, 2016.

[2] M. Jundullah, R. Umar, and A. Yudhana, "Analisis Penerimaan Sistem E-Learning Smk Negeri 4 Kota Sorong Dengan Menggunakan Technology Acceptance Model (TAM)," Semin. Nas. Teknol. Fak. Tek. Univ. Krisnadwipayana, pp. 724-729, 2019.

[3] W. O. J. Fhiter, R. Umar, and A. Yudhana, "Implementasi Dan Pengembangan Sistem Elearning Berbasis Web Pada STIMIK Muhammadiyah Paguyangan," Pros. Semin. Nas. Multi Disiplin IImu, no. Call for Papers UNISBANK Ke-3, pp. 104-107, 2017.

[4] S. E. Yulianto, "Pengaruh Persepsi Kemudahan Dan Persepsi Kemanfaatan Terhadap Pemanfaatan E-Learning Dengan Model Tam Di Smk Muhammadiyah 3 Yogyakarta," Jbti, vol. II, no. 1, pp. 1-14, 2011.

[5] D. Pibriana, "Technology Acceptance Model (TAM) untuk Menganalisis Penerimaan Pengguna Terhadap Penggunaan Aplikasi Belanja Online XYZ," JATISI (Jurnal Tek. Inform. dan Sist. Informasi), vol. 7, no. 3, pp. 580-592, 2020, doi: 10.35957/jatisi.v7i3.382.

[6] P. R. Yuliandewi, K. Agustini, and I. M. A. Pradnyana, "Wajah Dengan Menggunakan Technology Acceptance Model ( Tam ) Studi Kasus: Smk Negeri 1 Singaraja," Kumpul. Artik. Mhs. Pendidik. Tek. Inform., vol. 5, no. 3, 2016.

[7] N. Dalimunthe and H. Wibisono, "ANALISIS PENERIMAAN SISTEM e-learning SMK LABOR PEKANBARU DENGAN MENGGUNAKAN TECHOLOGY ACCEPTANCE MODEL (TAM)," J. Sains dan Teknol. Ind., vol. 11, no. 1, pp. 111-117, 2014, [Online]. Available: http://ejournal.uin-suska.ac.id/index.php/sitekin/article/view/564/536.

[8] A. Syafrizal, E. Ernawati, and Y. Dwiandiyanta, "Penerapan Model Technology Acceptance Model (TAM) untuk Pemahaman Media Pembelajaran Berbasis Multimedia Interaktif," Sci. J. Informatics, vol. 2, no. 1, pp. 9-14, 2016, doi: 10.15294/sji.v2i1.4524.

[9] W. O. J. Fhiter, R. Umar, and A. Yudhana, "Pengukuran Kesuksesan Implementasi ELearning," J. Edukasi dan Penelit. Inform., vol. 6, no. 1, pp. 122-130, 2020.

[10] T. Abe, A. Yudhana, and R. Umar, "Analisis Penerimaan Pengguna Terhadap Penerapan Sistem Informasi Perpsutakaan Menggunakan Metode Technology Acceptance Model," J. MEDIA Inform. BUDIDARMA, vol. 4, pp. 924-929, 2020, doi: 10.30865/mib.v4i4.2212.

[11] M. B. Suryawan and P. Prihandoko, "Evaluasi Penerapan SIAKAD Politeknik Negeri Madiun Menggunakan Pendekatan TAM dan EUCS," Creat. Inf. Technol. J., vol. 4, no. 3, p. 233, 2018, doi: 10.24076/citec.2017v4i3.113.

[12] F. S. Rahayu, D. Budiyanto, and D. Palyama, "Analisis Penerimaan E-Learning Menggunakan Technology Acceptance Model (Tam) (Studi Kasus: Universitas Atma Jaya Yogyakarta)," J. Terap. Teknol. Inf., vol. 1, no. 2, pp. 87-98, 2017, doi: 10.21460/jutei.2017.12.20.

[13] F. Fatmasari and M. Ariandi, "Penerapan Metode Technology Acceptance Model (TAM) Terhadap Penerimaan Krs Online," J. Ilm. Matrik, no. 3, pp. 135-144, 2014. 
BINA INSANI ICT JOURNAL ISSN: 2355-3421 (Print) ISSN: 2527-9777 (Online); 12 - 21

[14] F. Sayekti and P. Putarta, "Penerapan Technology Acceptance Model (TAM) Dalam Pengujian Model Penerimaan Sistem Informasi Keuangan Daerah," J. Manaj. Teor. dan Terap., vol. 9, no. 3, pp. 196-209, 2016. 